\title{
Chinese Traders in Ghanaian Markets: A Bag of Threat and Opportunities
}

\author{
MARK KWAKU MENSAH OBENG \\ University of Ghana, GHANA
}

\begin{abstract}
Although recent analyses on Chinese entrepreneurship in Africa attempt a departure from African opposition and present Africans response as more nuanced. Little is known of the characteristics and considerations that shape the complex positions of Africans to Chinese entrepreneurship in the distribution sector. This paper argues that Ghanaian trade actors' response to the presence of Chinese traders is a function of their socio-demographic characteristics and trading capacity. While the young, educated and large scale importers are opposed to their presence, the old, lowly educated and small scale traders and other allies forge various relationships of mutual benefits with the Chinese.
\end{abstract}

\section{Introduction}

Over the last decade and a half, there has been an increasing global interest in Africa's economy. A recent survey of 217 global companies across 45 countries by the Economist Group reveals that $65 \%$ of the companies outlined plans to expand into Africa as either an "immediate priority" or a "priority within the next decade"; while only $2 \%$ branded the African continent as irrelevant (Freemantle 2015).

The countries clamouring for a part in shaping the economic fortunes of the continent cut across the globe. Unlike in the past when the Western world was the dominant economic partner in Africa, increasingly today, the Chinese are competing fiercely with Europeans and Americans in the awards of major infrastructure development needs of the continent (Brautigam 2010; Kragelund 2009). This is because the economic door in Africa has been opened widely courtesy of liberal African investment policies imposed by western donors in the past decades (Kragelund 2009). This has re-emphasised Africa's position in the global economy both as a supplier of raw material and a destination for enterprise expansion (Ferguson 2006). While the Chinese presence is felt at the macro level as having greatly altered the aid architecture and infrastructural development on the continent, their presence is most strongly felt at the micro level, where a large number of Africans rely on the Chinese for access to global consumer items (Dobler 2009; Gadzala 2009). Although globalisation is seen to concern large transnational corporations, inter-state negotiations and multilateral institutions, it also affects small firms and individual actors who may operate outside of any obvious state-based agendas (see Gu 2009; Alden 2007). This notwithstanding, as Castles will point out, most of the analyses have adopted the top-down approach and fail to analyse the local effect of global economic and political forces (Castles and Miller 2009: 16). 
There is currently a plethora of studies documenting the increase in Chinese global consumables on the African continent (Bodomo 2012; Giese and Thiel 2012; Dobler 2009; Gadzala 2009; Mohan and Tan-Mullin 2014). These studies have revealed the active participation of both Africans and Chinese in this enterprise (Marfaing and Thiel 2012). Closely linked and emphasised in these works is the purported antagonism that exists between Africans and their Chinese counterparts in the African market space (Giese 2014; McNamee et al. 2012; Marfaing and Thiel 2011; Mohan and Tan-Mullin 2014; Haugen 2011; Lampert and Mohan 2014; Dobler 2009; Gadzala 2009). Central to this antagonism is the perceived threat the Chinese importers pose to the African players, which on several occasions have resulted in public protests (see Dittgen 2010; McNamee 2010).

Inspired by such orientation, even though both Africans and Chinese traders import these items into the continent, the Chinese are constantly accused of importing substandard commodities (Giese and Thiel 2012; Hagen 2011) necessitating many series of protests demanding their withdrawal from the market space. In Ghana, this has been led by the Ghana Union of Traders Association (GUTA) with their protest mostly in the Accra Business District area and to some extent in Kumasi Central market. The protest and agitations against Chinese traders in Ghana began in late 2005, according to TakyiBoadu (2005).

Fewer authors point, nonetheless, to the fact that Chinese traders have both tacit and conspicuous support within the same market spaces as those pushing for their removal. Even on the subject of antagonism, closer examination of the traders reveals a duality of response; while the literature records the demand for Chinese traders to be barred from the market, there are other traders who dissatisfied with the Chinese but do not necessarily demand their removal. The neglect of such accounts may explain how intractable the demand to remove foreigners from the markets has become (Giese 2014; Lampert and Mohan 2014).

In this paper, I suggest that portraying traders' response to the Chinese as solely antagonistic to the Chinese ignores the nuanced nature of the relationship between African traders and their Chinese counterparts. In doing this, I highlight three different responses of Ghanaian traders to the Chinese and argue that these three positions are determined by the traders' demographic characteristics and trading portfolios, which subsequently shape the extent to which the Chinese presence is welcomed or seen as a threat. I conclude that while the young, energetic, well-travelled and largescale importers are opposed to the Chinese presence, importers who are elderly and not as exposed as the former, propose a mutually beneficial 
relationship with the Chinese traders. The third, a composite group comprising of both traders and non-traders in the market space who benefit from the status quo, boldly supports the Chinese traders. The relationship between the Ghanaian trade actors and their Chinese counterparts are, therefore, far more complex than that which is described in the literature.

\section{Research Method}

The study employed a multi-local ethnography using multiple methods. The data was collected both in Ghana and China between May 2012 and August 2013 as part of larger study which sought to understand the networks and strategies that are utilised by Ghanaian transnational traders who import and sell Chinese manufactured products in Ghana. The adoption of the mixed method approach responds to one of the gaps in the literature on AfricaChina relationship, particularly at the people to people level (Bodomo and Pajancic 2016). Key among the ethnographic methods used were in-depth interviews with fifty Ghanaian importers of varied importing experiences. Thirty of these interviews were conducted in Accra and twenty from Kumasi [the two biggest commercial centres in Ghana]. To qualify for the interview, the traders had to be Ghanaian males or females who have travelled to China to import products for sale and are owners or managers of their trading outlets in Ghana. The sampling, therefore, excluded all other Ghanaians who are engaged in importing commodities of Chinese origin for personal or private use. The selections took place in locations such as markets, centres and shops in and around the Makola Market in Accra and the Central Market in Kumasi. These are centres known to host vibrant and active Ghanaians and foreign importers (Obeng 2015). A combination of accidental and snowballing methods was used in recruiting the traders. Furthermore, guided by the literature governing the tension and alliances in the distribution sector in Ghana (Amoah 2012), considerations such as gender, nature and size of import as well as years of importation were used in selecting potential participants. Similar approaches were used in recruiting the other categories of participants.

Next were interviews with five ${ }^{1}$ Chinese traders in Accra. These data were supplemented with five interviews with petty traders who source their wares from both Ghanaian and Chinese importers in Accra. Other interviews were held with two property owners (landlords) in the commercial business areas of Accra who have leased their properties to Chinese traders. The rest were interviews with three free-lancers (marketers) who work with Chinese

1 The researcher was constraint by his inability to speak the Chinese language and had to interview only traders who could speak English or were willing to speak through an interpreter. 
importers, three Ghanaian shop assistants of Chinese importers and five final consumers.

Additional data was solicited from Ghanaian residents in China whose livelihoods were connected to the import business. In all, a total of one hundred and seven (107) interviews were conducted to properly contextualise the narratives and experiences of Ghanaian trade actors. Eighty-seven of these interviews were conducted in two Ghanaian languages (Akan and Ga), whilst the rest were conducted in English. Interviews were conducted in either the shop or work-related venue of the participants. This offered the author the additional benefits of observing the activities of the participants and contextualising their voices within the relevant operational environments. The interviews conducted were transcribed and then manually analysed.

\section{Neoliberalism and the Ghanaian retail economy}

For decades, neoliberal theorists have advocated and forcefully pushed for the opening of economic spaces and the removal of all forms of economic barriers as key to turning around the economies of developing countries (Kragelund 2009). This has been seen in the humongous phase of creating the enabling environment for economic take-off. In this process, it has been suggested that government has no business in doing business and that instead should use its powers to provide incentives, regulations and economic programmes conducive for the private sector to thrive. When this is done, businesses and the private sector christened as the engine of growth will respond positively (Danilovich 2006). The country will subsequently benefit from the trickling-down effects of private investments in the form of taxes for government and employment opportunities for citizenry. Yielding to these policy objectives was a prerequisite for any financial assistant to any third World Economy (Kutz 2002; Fraser and Lungu 2007; Kragelund 2009). In line with this and under the dictate of the International Financial Institutions (IFIs), Africa embarked on a series of reforms. These were christened variously as Economic Recovery Programmes (ERPs) and Structural Adjustments Programs (SAP) and came with the pledge to increase economic growth and to correct imbalances between government spending and government revenues. This was also going to raise the productivity and capacity of African economies (Kragelund 2009: 489). The most widespread measures used included trade liberalisation, exchange-rate liberalisation (devaluation), fiscal and monetary reforms, public enterprise reforms (retrenchment), and the deregulation of investments, labour and prices. Although ERPs differed slightly from country to country, in most cases the IFIs were successful in liberalising the investment codes of African economies 
to accommodate a catalysing role for FDI in the transformation process (Hutchful 2002). However, the employment opportunities that were to follow with 'promised expanded economies' and modernised agriculture eluded many Africans. Instead in many places as a result of trade liberalisation and years of economic mismanagement, many of the state-owned enterprises (diverted and state-managed) collapsed due to increased competition, resulting in massive unemployment (Kragelund 2009).

While reports on the impacts of neoliberal policies in the sub-region have generally been negative (see Odutayo 2015; Agymang-Konadu 2002; Brydon and Legge 1996; Ayittey 1991), in Ghana the adoption and implementation of the SAP had a major impact on trade and the import enterprise in a number of ways. First, it altered trading as a women's field. With people losing their employment as part of the public-sector rationalisation, a number of men joined the import business. Awumbila et al (2011) report that in Kumasi, men opened shops and created new spaces called the 'Line 18' in the Central Market. This hosted mobile young men who imported essential commodities from Lomé, Togo and Lagos, Nigeria and sold them in the local markets. A similar observation is made in and around the Makola Market in Accra. The increased number of traders thus decreased the potential profits to individual traders while increasing competition among the traders.

At the same time, efforts toward trade liberalisation enhanced the import enterprise. Interventions such as abolishing of a $10 \%$ sales tax on import, the establishment of a parallel foreign exchange market by issuing licenses to private citizens to set up foreign exchange bureaus, and the eliminations of import licensing amongst others boasted the importation and trading in global consumer items (Darkwah 2002; Rimmer 1992). Additionally, the SAPs had a negative impact on the manufacturing sector as a number of the companies which were divested as part of the transition failed to survive, with a sizeable number of them eventually collapsing. This served as further motivation for the thriving import enterprise (Obeng 2014). People had enough incentives to import any consumable from across the globe so far as they envisaged a market without any threat from domestic manufacturers. The business of importing and selling foreign products became popularly knowns as 'Accra-London-Accra' business (Darkwah 2002:1). The phrase gained its popularity because the UK has since early times of migration been a common destination for many Ghanaian emigrants. Other destinations included New York, Washington, Milan, and Hamburg. The importers were people who commanded sizeable incomes and described as businesswomen [and men] of high social standing (Darkwah 2007). Importing from these advanced western countries was therefore, a preserve of the few Ghanaians who could command the huge economic resources as well as the appropriate social networks (Bowles 2013; Darkwah 2007). 
The players in the import business and trading in global commodities thus prospered (Bowles 2013; Bodomo 2012; Darkwah 2007) and for many it served as the last resort to making a living in Ghana. Ghanaians who lost their jobs as a result of the implementation of SAP looked up to the trading sector, as did the many who could not find employment in the formal sector as a result of the contraction in the economy. The sector was therefore dominated by Ghanaians with little or no competition from foreigners. The few foreign operators operated as mass-retail market, generally perceived as serving the affluent in society. Their activities, therefore, hardly threatened the many Ghanaian importers and traders. The seeming monopoly enjoyed in the market space by Ghanaians is currently being challenged with the increasing arrival and visible presence of Chinese traders and other traders from West Africa in the local market.

This is a new challenge for the Ghanaian state because of its dual allegiance. In one vein, the state is expected to promote and protect foreign capital to stimulate economic development but at the same time to do so by protecting the citizens' interest. In this sector government hands appear to be tied. To protect the activities and interest of Ghanaians in the retail sector the government policy (Ghana Investment Promotion Centre (GIPC) Act), that was developed with the assistance of the IMF and the World Bank to help attract the needed FDI into the country, offered Ghanaians protection from foreign competition. This GIPC Act (ACT 478) of 1994 and now 2013 (Act 865) regulates the participation of foreigners in the economy, with the exception of those in the mining and petroleum exploration. The amended GIPC Act of $2013^{2}$ makes two demands on foreigners who desire to invest in the distribution sector, be it wholly or jointly. The first demand is the investment of a minimum of US $\$ 1,000,000.00$ [used to be US $\$ 300,000.00$ ] cash or goods of equivalent value. The second is the employment of at least 20 skilled Ghanaians [used to be 10 Ghanaians]. These legal measures are aimed at attracting big international players, and at the same time, aimed at protecting the local informal trade as one of the major employment generating sectors within the country (Giese 2014). When these conditions are met, the enterprise qualifies for automatic expatriate quota depending on the amount invested. According to the regulations, a foreign-registered business qualifies for a quota of two expatriates if the investment is US\$100,000 or more but less than US $\$ 500,000$. These two demands exclude other costs which must be borne by the expatriate before the business can take off. Giese and Thiel (2012)

2 The 1994 GIPC Act was amended in 2013 to address pertinent issues deemed critical and in response to the demands of Ghanaian importers. With the exception of a few inclusions, the major thrust of the amendment was the raising of certain boundaries in an attempt to safeguard the Ghanaian actors' interest and preserve the restriction on foreign participation in the retail sector. 
report of a number of additional expenses including a vending space which must be rented for five to ten years with an upfront payment of between US\$ 25,000 to US $\$ 60,000$ depending on the size and location of the facility. Additional investments include the renting of a warehouse from where the shops will be restocked; a residential accommodation for the investor and one or two of his family members, business partners or Chinese employees; and the purchase of a car (Giese and Thiel, 2012: 4). Going by the law and local market conditions, a foreigner setting up a distribution business in Ghana requires not less than US\$1.2 million or its equivalent in Ghana cedis.

\section{Chinese Traders in Ghana's Market Space}

The number of Chinese entrepreneurs arriving in Africa has risen steadily over a decade and has now passed the one million mark (Gadzala 2009). Apart from those who are engaged in state-sponsored large-scale constructions, who are more likely to return home after the execution of the project, there are thousands more who are in Africa as economic migrants and undertaking economic activities in a more permanent manner even though they see their presence as transient (McNamee et. al 2012; Ho 2008).

The activities of the majority of these Chinese have been described as independent of the state (Haugen 2011; Marfaing and Theil 2011; Gu 2009):

"with rare exceptions, Chinese small business owners have never had contact with the Chinese embassy or officials in the country they operate in; indeed, the near unanimous perception of 'Beijing' amongst them is negative" (McNamee et al. 2012: $7)$.

These actors, referred to as independent Chinese entrepreneurs by Marfaing and Thiel (2011), constitute the fifth stream of Chinese actors in Africa whose activities, according to $\mathrm{Gu}(2009)^{3}$, began after 2005. Marfaing and Thiel (2011:4) summarise this category of Chinese migrants and their activities in Africa as follows:

Largely independent from the big Chinese players, they come to Africa not as workers in the highly prestigious state projects, but rather to follow their own economic interest, engaging in business activities as diverse as petty manufacturing, printing, pharmaceutical and medical services, restaurant, beauty salons and general trade (Emphasis mine).

While these entrepreneurs act independent of the state, a number of policy decisions undertaken by the People's Republic of China implicitly underlie

\footnotetext{
3 The first stage (1949-1980s) related to Chinese aid projects; the second (1980s to mid-1990s) involved large SOE trading companies; stage three (mid-1990s-2000) saw the entry of large SOE and private companies into manufacturing often involving linkages from resource based and infrastructure investments; stage four (2000-2005) saw the growth of spill overs from these earlier large-scale investments, and in the most recent stage (post-2005), the entry of a new family of small-scale private sector Chinese firms into Africa.
} 
their rising presence and strength in Africa. These include abolishing the state trading companies, the financial boost provided by the Export-Import Bank of China, and the China-Africa Development Fund set up by the China Development Bank and the open-door policy which liberalised emigration in 1985. (See Wang 2007; Brautigam 2009). These policy interventions directly and indirectly led to a ballooning of the Chinese presence in Africa as firstgeneration migrants from mainland China joined the established population of Chinese, whose roots can be traced back to the 'coolie trade' in the nineteenth century (Haugen 2011: 164-5).

Although the presence of the Chinese in Ghana dates as far back as the colonial era, the number and their activities since the turn of this millennium have become very conspicuous (Gadzala 2009: 209). The estimates range between 2,000 and 10,000 people depending on the source (Mohan and TanMullin, 2009; Ho 2008; Sautman and Hairong, 2007) ${ }^{4}$. Trading in consumer goods is one area where the Chinese presence in Ghana is raising most concern among players, apart from the small-scale mining. This is in spite of the huge financial barrier that the GIPC ACT of 2013 places on their activities. Explaining how the financial barrier is failing to deter the Chinese in Ghana, Giese and Thiel assert that although the almost $\$ 1.2$ million required for participation appears to be huge by both Ghanaian and international standards, the legal framework also opens a massive window for it to be abused with little or no consequences. They opine that even though the investor is to provide proof of either a foreign currency account balance with a Ghanaian bank or goods of equivalent value at the time of registration, since the proof of the investment is only required temporarily, it is easy for Chinese entrepreneurs to raise this 'capital' within their kinship-based social networks to facilitate the registrations and to withdraw the same amount afterwards (Giese 2014:3). This strategy therefore makes nonsense of the financial barrier. Additionally, enforcement of this requirement is loosely implemented, creating unfettered access to the market. In fact, many of the international operators in the Ghanaian market are currently operating outside the legal regime (see Haugen 2011; Gadzala 2009). For example, data from the GIPC indicates that only 147 Chinese companies were registered between 1994 and 2011 to engage in general trade, even though there are many more operating across the length and breadth of the country.

The intention of the ACT to attract large international investors who would supply, rather than compete with established local merchants and, moreover, create employment has, therefore, become more of a mirage (Giese 2014),

4 Migration of Chinese people into Ghana dates back to the 1940s. Originally, most of them came from Hong Kong because at the time, the two territories were under British colonial administration (See Ho 2008). Migration from mainland China began only in the 1980s. 
culminating in the traders' taken positions that typify the theory of ethnic antagonism.

\section{Ethnic Antagonism: Ghanaian Trade Actors ${ }^{5}$ Response to Chinese traders}

An analysis of the responses of Ghanaian trade actors to the increasing presence and competition from Chinese traders in the market space represents a manifestation of ethnic antagonism. The theory of ethnic antagonism, which was first used to analyse the split of labour market in the United States of America, is a synthesis of ideas previously used to study Japanese-White conflicts in the US (see Cox 1948: 408-22) and the analyses of the responses of Brazilians on the subject of 'colour lines' (See Harris 1964: 70-94). Ethnic antagonism theory is in contrast to both the Marxist and nonMarxist assumption that racial and ethnic or cultural differences in themselves prompt the development of ethnic antagonism. The theory rather suggests that economic process are more fundamental to the formation and cessation of antagonism. The theory argues that for there to be a labour split, a labour market, must contain at least two groups of workers whose price of labour differs for the same work, or would differ if they did the same work (Bonacich 1972: 549). This results in two movements: the exclusion movement and the caste system. Bonacich cites the 'white Australia' policy; as an example for the former and South Africa's colour bar to illustrate the latter. Again, the United States has shown both forms, with a racial caste system in the South and exclusion of Asian and 'new' immigrants from the Pacific and eastern seaboards respectively (Bonacich 1972:548). This theory has previously been used to understand a number of phenomenon including higher education (Jacques 1980) and non-sectarian social movements (Nagle 2013), anti-immigrant sentiment in mainland China (Downes 2017) and racial-gender analysis in nonstandard employment (Branch and Harley 2017). In the exclusion movement, efforts are made to prevent an ethnically different group from becoming part of the society. In the other, an ethnically different group is viewed as essential to the society but must operate within some limitation to facilitate the economic achievement of the other diverse group (Bonacich 1972).

Bonacich explains that the use of 'ethnic' subsumes 'race' in its application since the latter is a more generic term. Ethnic thus refers to a group defined socially as sharing common ancestry in which membership is therefore inherited or ascribed, whether or not members are currently physically or culturally distinctive. Similarly, Bonacich delineates the use of the term 'antagonism' to encompass all levels of intergroup conflict, including ideologies and beliefs (such as racism and prejudice), behaviours (such as

5 I chose to use actors and not traders because the list includes other participants who are not traders but are active actors in the market space. 
discrimination, lynching, riots), and institutions (such as laws perpetuating segregation). Antagonism thus allows for the possibility that conflict is mutual and a product of interaction and not only emanating from one side (the majority side). Ethnic antagonism emanates from different motives, which subsequently create differences in demand for earnings and economic rewards. For instance, Bonacich discuses temporariness versus permanency in the labour force and categorisation of income goal; as fixed or supplementary income. Applying the theory to the responses of Ghanaian traders to the Chinese traders in Ghana, two variables are identified as exerting significant influence on the actions of the various trade actors. These are trading capacity and socio-demographic characteristics of the actors. These two variables, depending on how they affect the actors in relation to the Chinese presence, could either worsen or enhance their economic interest and other livelihood choices, which in turn determine their respective responses to the Chinese presence in the market. I identify and discuss the three observable relationships between the Ghanaian trade actors and their Chinese counterparts next: competitive, complementary and collaborative.

\section{Competitors}

This set of traders is similar to those identified in Kenya, Cape Verde, and Nigeria and other parts of Africa (Lampert and Mohan 2014; Haugen 2011; Gadzala 2009). They are experienced transnational traders who continue to import global consumables for sale in Ghana with China as one of their main import destinations. They are relatively young; most of them are in their late thirties and not more than fifty years of age, and are well educated (tertiary level). They envisage their economic wellbeing in the import business and do not intend quitting anytime soon. Another distinctive feature of these importers is the fact that they import similar goods as the Chinese: male and female suits, men's shirts, men's shoes, building materials (floor and wall tiles), electrical appliances and stationery items.

Compared to other categories of Ghanaian traders, these traders command a lot of resources and import in large volumes ${ }^{6}$. As a result of their resourcefulness they generally wield political influence. They also have the capacity to procure a letter of invitation ${ }^{7}$ from a major supplier in China but may not necessarily process their visa in person (see Obeng 2015). The traders and their activities fit Asamoah's (2007) Marxist description of national bourgeoisie. This is because they command sizeable financial resources

\footnotetext{
6 A minimum of a 20 -foot container per trip.

7 As a measure by the Chinese authorities to regularise the number of persons who enter the country and to ensure that all persons who enter the country have legitimate reasons to do so, the immigration service now insists that all persons desiring to enter China must produce a letter of invitation as a prove of legitimate business/duty.
} 
which are independent of foreign capital. These traders, until recently, had an estranged relationship with the state (Darkwah 2002). Nkrumah, the first president of Ghana, for example, promised to reduce their influence in the national economy:

...this type of business serves no social purpose and steps will be taken to see [ensure] that our banking resources are not used to provide credit for this type of business. (Nkrumah 1973: 202).

True to his words, Nkrumah and subsequent regimes instituted measures including restricted access to import licensing, use of quota, restriction to forex and the adoption of the Import Substitutions Industrialisation programme that made import an expensive enterprise (see Garlick 1971 and Darkwah 2002).

Researchers such as Garlick (1971), nonetheless, assert that Nkrumah's antagonistic posture towards Ghanaian importers was motivated by his fear that the emergence of a class of upwardly mobile businessmen would pose a threat to the stability of his government.

This discontent towards traders continued on several fronts and regimes until the government signed up for the Bretton Woods sponsored economic recovery programme in 1983 (Ocquaye 1995: 260) which led to the liberalisation and the deregulation of imports (Darkwah 2002).

With such a treacherous past, the traders vehemently oppose the presence of foreigners, in particular the Chinese in Ghana's markets, and demand their outright withdrawal from the market space. Guided by the ethnic antagonism theory, the traders who I described as competitors will fit into the exclusion movement. In this movement, the large scale, experienced, well-resourced and well-connected traders who perceive the presence of foreigners in the Ghanaian market as chipping away their economic livelihood, direct their efforts at preventing or excluding the Chinese traders from the market. In pursuit of this agenda, the Ghanaian traders employ a number of arsenals and justifications to realise their objectives. In 2012, these traders represented by their association, (GUTA), put intense pressure on the government to enforce the laws regulating trade in Ghanaian markets. They threatened shop lockup, among other threats. In response to the traders' demands, two major things happened. First was the setting up of an inter-agency taskforce to ensure that only certified foreigners operate in Ghana. A number of shops operating illegally by foreigners were locked subsequently. The second was the amendment of the GIPC Act in 2013.

These interventions have, however, failed to yield the anticipated outcome and the pressure on the state keeps mounting. In June 2014, GUTA declared a four-day lockup to demand the withdrawal of foreigners from the market 
space (Daily Graphic 2014). Even though there are other foreigners in the market space, the Chinese are their main target because of their numbers as well as their competitiveness. To buttress their arguments, the traders cite issues such as loss of employment opportunities, the collapse of their businesses and the potential social cost of the collapse of their businesses ${ }^{8}$.

In making their demands for the Chinese to be repatriated, the traders also draw on other areas of Chinese incursion into the country (although this has little or no impact on their businesses). This is how Mr Beachem, a trader in Kumasi, explains the Chinese presence, touching on almost all the perceived challenges that the Chinese presence poses to the livelihoods of local traders:

Their presence in Ghana affect us negatively. We are losing our jobs to them. Meanwhile, when you go to China, your activities are restricted. You are given just 30 days but they come to Ghana and stay as long as they want. If there is a shop for rent, the Chinese are quick to pay for it and you a citizen is left without a job. Even now in Obuasi [one of the major mining communities in Ghana], the Chinese are competing with the 'galampsey' [small scale mining] miners. They even wield ammunitions which they sometimes use against the Ghanaian miners, yet nobody seems to care about those lives9.

Implicitly, for these traders, the practice is gaining ground and festering because of the failure of the state and its agents to act in a timely and appropriate manner. Culminating further in this discontent as expressed above is the active involvement of the Chinese in the artisanal gold mining sector in Ghana. Over the past decade, tens of thousands of Chinese nationals have migrated to rural Ghana, where they have proceeded to extract gold illicitly, for the most part undeterred. The Government of Ghana's response has nonetheless been very pedestrian and unsustainable. It is supposed that the high world market price of gold is a driver of the influx of individuals (both legal and illegal) (Armah, Luginaah, Taabazuing, and Odoi 2013). For instance, there was a National Task Force formed to 'flush out' illegal miners in June 2013. About 168 Chinese nationals were arrested, some of whom were immediately deported. The vast majority were in possession of expired visas and/or work permits; others, however, had no identification documents (Hilson, Hilson and Adu-Darko 2014).

These traders also accuse their fellow Ghanaian traders of encouraging 'the Chinese invasion'. They blame some of their compatriots of misconstruing

\footnotetext{
8 This sentiment is similar to the position that was espoused by the Minister of Interior in 1969 justifying the eviction of other nationals from Ghana. In other quarters, this sentiment has been described as xenophobic.

9 A few days before this interview, The Chronicle Newspaper, a national daily reported that gun-wielding Chinese miners had killed two Ghanaian citizens in Obuasi. Pictures of the Ghanaians shot lying in a pool of blood as well as the Chinese miners accused of killing them were published in the May 10, 2013 edition
} 
'being hospitable' to preference for foreigners, even at the expense of the Ghanaian interest. They make reference to others who they accuse of knowing the negative effects of the Chinese traders' activities, yet sacrifice the interest of other Ghanaians for their personal and immediate satisfaction.

The following conversation with Mr Agyarko, a spare parts dealer [an enterprise whose profitability is yet to be compromised by the Chinese incursion] at Abossey Okai10, shows his discontent with the Chinese in Ghana. He also believes their activities have the potential of collapsing his business. He states:

Ghanaians say they are hospitable and so that is the outcome... while the Chinese government wants employment for its citizens, we say we are hospitable. Very soon, I am sure it will be difficult for Ghanaians to go to China and buy goods.

Explaining the latter point further Agyarko states:

It is a strategy. The Chinese are smart. Ghanaians only think about immediate satisfaction. We are same people who buy from them and we complain that they have taken over our jobs. If you don't buy, someone else will. I have a friend who sell mobile phones. He told me the Chinese have been coming to supply him products. The person says the Chinese have taken over their business; meanwhile, they are the same people who buy from them.

On how the Chinese are able to out-compete the Ghanaians in spite of their superior folk knowledge, the competitors unanimously rejected the wideheld proposition that Ghanaian traders demand huge profits. Instead, they attributed their inability to compete favourably to external factors. Five related factors are gleaned from these traders, namely accusation of corruption within government agencies, mass import, familiarity with the import destination, cheaper source of finance and unimpeded entry into the Ghanaian market, which all play to the Chinese advantage.

The Ghana Standards Authority and the Ghana Revenue Authority are two of the agencies mostly accused by the traders. The former is accused of allowing the Chinese to import 'substandard' products into the country. This is, however, challenged by Giese and Thiel (2012), who see it as a ploy to divert attention from the local culprits since there are Ghanaians who import products of similar quality yet are not subjected to such allegations. Lampert and Mohan (2014) make similar observations, citing a Ghanaian industrialist who asserts that such products are not brought in by the Chinese but instead by Ghanaian and Nigerian traders.

10 A commercial centre in Accra traditionally known for the sales and repairs of vehicular parts and other used vehicle hardwares. 
Similarly, the Ghana Revenue Authority is accused of not demanding the rightful import duties from the Chinese thereby making their items cheaper. Akpeto, who imports men's suits and shirts, registers his displeasure below:

You see, this line of business is gradually being taken over by the Chinese because they can even sell what is being sold for GH\$30.00 at GH\$ 18.00. I wonder if they pay the same duties as we do. I am losing almost all my contracts because when I send my goods, I am told that the Chinese are offering a cheaper price; They sell these at the China price and I now believe they don't pay the right duty (Akpeto, Makola Market, 2012).

This accusation is flatly disputed by the destination inspectors of the Customs, Excise and Preventive Service (CEPS) ${ }^{11}$ division of the GRA and the Chinese traders. CEPS explained that the current regime makes it almost impossible for any officer to vary the schedule to the advantage of the importer, irrespective of one's nationality.

The second factor is mass import by the Chinese. On this subject, all the traders, irrespective of their position on the Chinese in Ghana, are aware of the advantages that come with large imports. This is how Mr Lamptey who sells in the Kumasi central market analyses the impact of mass imports on the business:

...in China and in the world over, the larger you buy the cheaper it becomes. So if I go to China and I say I want to buy 1,000 pieces, I will get it cheaper than someone buying only 200 pieces. So if one goes to the factory and buys 20,000 pieces of white shirts, he gets it very cheap so I cannot compete with him and I cannot afford the quantity he is buying also so they obviously start ahead of us and we cannot ever catch up with them.

Complicating their plight is the practice where manufacturers or their representatives choose to export their product into Ghana directly in order to free-up their stock. Charlotte explains as follows:

'...one time, I met the factory owner from whom I import most of my products to Ghana. He was here to sell locked-up products at very cheap prices himself because he finds it difficult to sell in China. In that case, it is impossible to compete with such a person. He only put some small margins to cover his transport, etc. so he could dispose of the products in a short time (Charlotte, Makola Market, Accra: 2013)'.

\footnotetext{
11 This unit of CEPS exercises over sight responsibility for the valuation and classification of imported goods in the country. Since 2001, a number of private companies have been engaged to undertake these services on behalf of the State but the service still exercises the final authority. Clients who are dissatisfied can appeal to the Commissioner for redress.
} 
Another factor that maintains the price gap between the Chinese traders and the Ghanaian traders is the relevance of the strength of closed networks. Drawing on the strength of relationships in this sense is synonymous with the concept of 'guanxi', an influential concept in doing business in China. Studying the activities of the Chinese in Zambia, Gadzala (2010: 47) observed that:

First, trust between Chinese people is highly circumscribed, rendering networks equally exclusive: a person trusts members of their family or lineage absolutely; friends and business partners are trusted to the degree of mutual obligation; people outside the person's networks are mistrusted.

A similar observation was made in Ghana by Giese (2014:3) stating that:

...many of the hundreds of Chinese traders originate from the Zhejiang province, though small scale by international (but rather large by Ghanaian) standards, enjoy close kinship links with specialised light industrial producers for which their province is famous... in this way, for instance, the approximately one hundred Chinese importers of footwear have become a dominant force, with a $30 \%$ to $40 \%$ share (by value) of all shoes imported from the People's Republic of China (PRC).

Some of the Ghanaian traders were aware of this practice among the Chinese traders:

'If a Chinese comes here, what does he need? For all you know, it has been given to him on credit by a family member at a certain percentage so he doesn't really care whatever amount he sells the items. So when he comes and sells and gets something little, he is okay and he goes away happy (Mr Agyarko, Makola Market 2013)'.

Closely connected to this observation is the superior knowledge, skills and familiarity to the Chinese market which further enhances the Chinese prowess in Africa. The Chinese were aware of this and thus wrote off the African ability to compete with them. Haugen reports as follows:

'The Chinese envisaged the African as lacking both the skills and the zeal necessary to succeed in a treacherous Chinese business environment which required extreme vigilance as well as good bargaining skills for a successful purchase (Haugen 2011:167).

Finally, the Chinese, unlike their African counterparts in China, enjoy relatively unhindered travelling access to Ghana. In general, the immigration regimes in African countries are more relaxed than in China, with good opportunities for obtaining long-term and multiple-entry visas or residence permits. Chinese traders can, therefore, travel between the point of purchase and the point of sale, which enables them to be updated about the market conditions at the point of sale while retaining control over the procurement in China (Haugen 2011:169). The free access and unhindered navigation are not available to African traders in China. The African traders also complain about difficulties in obtaining a visa to China. Those who dare to stay beyond 
the limits imposed by their visas or permits in China face imprisonment, fines and repatriation if caught. They must, therefore, be cautious when they move about, which constrains their business opportunities and increases transaction costs (Bodomo 2012).

\section{Complementarity}

There are also Ghanaian traders who propose a complementary relationship with their Chinese counterparts. From the Bonacichian perspective, the modalities of this proposal represent a caste system. They do not wholly support the Chinese presence in Ghana, yet do not demand their eviction. For this type of trader, the Chinese importers, an ethnically different group are essential to their ability to achieve their objective: to make reasonable returns selling imported Chinese made products without having to import directly from China. To achieve this, however, requires that the state must draw a clearer boundary between what the Chinese traders are allowed to do and not do, and this should be strictly enforced. They argue for the activities of the Chinese to be limited to wholesaling and estopped from the ongoing 'freerange' activities, including retailing and hawking. Essentially for this category of traders, their partial tolerance for the Chinese traders is motivated by their ability to exploit their presence for personal economic gains.

This position is influenced by some structural constraints associated with their trading activities. Regulating the activities of the Chinese in Ghana will, therefore, become one of the options through which they will be able to surmount some of the challenges and accomplish their business interests. Ninson, a 57-year-old experienced importer, who currently struggles to cope with the rising cost of import and in particular the stress involved in importing directly from China expressed his position as follows:

...so instead of you going through the stress of travelling and paying import duties and transportation, it will be prudent to buy from them [Chinese traders in Ghana]. The problem I have with the Chinese traders is that they retail. I will appreciate if it was restricted to wholesaling; that way, we also remain in business.

Ninson had earlier explained how over the period of 5-7 years, the price difference between what he buys from the Chinese traders in Ghana and those items he imports in person is gradually becoming insignificant. To Ninson and others in this category, the price difference does not represent enough compensation for the personal stress, the sacrifices and resources mobilised in order to import from China. Their interest will, however, not be enhanced if the Chinese continue in the retail business. The Chinese activities in Ghana will thus be seen as a win-win situation if they only serve the bulk buyers such as himself and not the final consumer. 
Kofi Okyere shared a similar view by calling for their activities to be restricted to the main cities and at the wholesale level:

Currently, the Chinese have come to Ghana in droves, instead of getting a warehouse, they are in the market and retailing like everyone else. What makes it worse is that they are also invading the villages and small communities and are competing with us. (Kofi Okyere, Kumasi Central Market).

A further review of the traders in this category reveals four other conditions apart from price differentials that predisposed them to enter into a complementary relationship. These traders are relatively advanced in age, are dissatisfied with the stress involved in importing directly from China, and are constrained by the delays and difficulties associated with the visa acquisition process. Finally, they also face a major challenge in constantly mobilising the needed financial resources to ensure a thriving import business.

Madam Agyapong, a 53-year-old woman, who has been in the import business for almost two decades makes this point more succinctly below:

...China is really far and I am getting old. I always return extremely exhausted. The food I cannot eat; so for me, now, I am even considering stopping this trip. I will be re-stocking from the Chinese here in Ghana (Madam Agyapong, Makola Market, 2013).

This gets more complicated when the traders have to combine these inconveniences with the visa procurement challenges. As a result of the increasing number of people who desire to travel to China, the Chinese authority has tightened the visa requirements. The traders are required to show evidence of legitimate business in China by providing an official documentation from an accredited Chinese distributor. Procuring this as well as the local process of applying, submitting the visa form and attending interviews at the embassy are getting more complicated for many. Quite a number of the traders thus opt to apply for the visa by proxy at an exorbitant cost which further makes them uncompetitive.

The proxy, however, in many instances, does not guarantee them the visa. Cynthia's commentary below sums up the growing difficulties the traders face in acquiring a Chinese visa:

...at first, you could be given a six-month multiple entry visa within a few days of submitting the application. Today, even the single entry for 30 days has become a challenge. Sometimes, you have to apply for about four times before, if you are lucky, one will be approved (Cynthia, Kumasi Central Market: 2013).

To make matters worse, when their applications are refused, no specific reasons are offered. This makes it difficult for them to identify what they need to do in order to secure the visa. Some commented sarcastically that they 
believed the process of evaluating the application is done in the form of a lottery with no 'rhyme or reason'.

Some of these traders have had to resign their faith to this arrangement because they view the visa challenges as a part of a ground scheme by the Chinese authority to monopolise the distribution sector in Ghana and are only using the refusal as a means to accomplish this project. Given that these traders are at the mercy of the Chinese embassy officials, the only option is to work with the Chinese in the Ghanaian market space. However, this will only work if their activities are streamlined to protect their turf by ensuring that the Chinese activities are limited to the wholesale and restricted from participating in the retail sphere.

\section{Collaborators}

A third group can also be found in the market space of Ghana. This group, unlike the two previously discussed, represent a composite population in the market space but are united by the benefits they derive from the presence of the Chinese traders in the country. This group is satisfied with the status quo and, therefore, oppose the state's efforts at regulating the presence of the Chinese. They comprise the 'business associates' of the Chinese investors, workers in the Chinese shops, petty traders (who lack the capacity to import directly from China), landlords and, individual final consumers.

Below is an analysis of how these categories of trade actors' benefit from the Chinese presence:

The final consumer enjoys the benefits of lower cost of items purchased compared to those purchased from the Ghanaian operated outlets and, therefore, makes some savings purchasing from the Chinese outlet. Similar benefits are enjoyed by the petty traders who re-stock from the Chinese outlets. This is because they are able to make more returns on their sales.

Another factor that the petty traders allude to in their support for the Chinese retailers is their punctuality and reliability at work. For example, the Ghana Business News on November 21, 2012, which reproduced a report that was generated by the Ghana News Agency (GNA), makes attribution to a trader named Nana Ama, [a shoe seller] who disagrees with the demands of GUTA for the government to repatriate the Chinese traders, because for her 'the Chinese are more punctual and never keep their clients waiting as compared to their Ghanaian wholesalers'. The same report cites another trader saying 'they [the Chinese] always meet my specifications as compared to Ghanaians who would offer me what was available and not what I requested'. 
For these traders, therefore, the solution was not to demand the removal of the foreigners but it was for the Ghanaian importers to have a change in their attitude towards business. Nana Ama makes this point clearly below:

'when these foreigners started trading in this area, all the rich people [large scale importers] were here but because of their high prices and poor services, we had to shift to the Chinese. (Nana Ama, Accra: 2012).

The next group of collaborators are the "business associates". They are presented as partners to the Chinese entrepreneurs even though the general perception about them is that they do not have any financial stake in the venture except the use of their nationality to facilitate the Chinese investment. The practice, termed as fronting though criminalised, remains common because evidence of the effect is difficult to procure. The practice is popular for foreign investors because it reduces the initial capital requirements and also simplifies access to other related processes, such as business registration, tax clearance and the filing of VAT returns. Fronting also saves shields the Chinese firms from the routine security checks aimed at flushing-out illegal traders. In whatever capacity these Ghanaians associate with the Chinese, what is not in dispute is that the Ghanaian earn income through their association and are thus better off having the Chinese in Ghana. This practice has been observed in Cape Verde as well (see Haugen 2011).

The next group are the workers. These workers can be categorised into two, based on their routine duties and remuneration practices. These are the labourers and the commission-based sales personnel. The labourers are on a fixed wage payable weekly or monthly and usually liaise between the Chinese owners and their clients. They are responsible for carrying and packaging items sold, do all the menial jobs and errands for the employers. The second set of employees, the sales personnel (remunerated on commission) are not always at the sales outlets as they may be in search of potential buyers. The economic survival of these people is thus tied to the continuous operations of the Chinese in the market space. To send the Chinese packing means a loss of economic livelihood in a country where the unemployment rate is rising, even for the skilled.

The last set of actors who support the presence of the Chinese in the Ghanaian market space, though usually invisible, are the owners of retail outlets. Rents have positively been affected by the increasing presence of foreigners to their advantage. These, according to the participants, have risen closed to $100 \%$ over the past five years. The landlords now enjoy the luxury of demanding their rent in foreign currency ${ }^{12}$ particularly the US dollar, a practice that favours foreigners. This is how John Mensah, an executive member of GUTA

12 The local currency consistently depreciates against all the major foreign currencies. The cedi, thus, loses its potency as a store of value. A foreign currency becomes a priceless asset to keep. 
expressed his frustration towards the practice as he justified GUTA's support for the removal of the Chinese traders:

The Chinese should be deported. They are making our lives very uncomfortable. You see, now because of them even landlords and shop owners have increased the rent of their shops and sometimes even prefer the dollar to cedis, which many Ghanaians cannot afford.

In summary, for the collaborators, should the demands of GUTA as well as the dictates of the GIPC Act be enforced, they will be at risk. While the petty traders will have a reduction in their profit margins, the final consumer will have to spend more on procuring their products. Similarly, the business associates and the workers will lose their source of income and the landlords, a loss in their new found economic investment.

\section{Conclusion}

The bulk of the existing body of work on the relationship between Chinese and African traders focus primarily on the antagonistic nature of this relationship (Giese and Thiel 2012; Haugen 2011; Gadzala 2009; Haugen 2011; Carling and Haugen 2005). In this literature, African traders' antagonism to Chinese traders is presented in monolithic discourse, asserting that all traders demand a removal of the Chinese from Africa's economic space. Drawing on Bonacich's theory of ethnic antagonism, this paper argues that presenting African traders' opposition to the Chinese in a manner that glosses over the nuanced and more complex responses of African trading actors to the Chinese. On the theme of antagonism, this paper categorises African responses into two, firstly the exclusion movement; classified as competitors who perceive the presence of the Chinese traders as a threat to their economic interest and survival and thus demand their complete withdrawal. The second response is the caste-system identified as the 'complementary', who though they are opposed to the Chinese, propose a segregation of the market's permissible space for the local traders from that of the Chinese traders in such a way that the continuous presence of the Chinese remain beneficial to their economic aggrandisement. A third position which the literature has been loudly silenced on is discussed. This refers to a group that is passionately in support of the Chinese in the market space. Secondly, the paper suggests that undergirding these varied positions are not merely cultural differences but that they are fundamentally a product of both structural and demographic factors that challenge the economic sustenance of these actors. While it is indeed true that antagonism does exist between African traders and their Chinese counterparts, the nature of the response is subjected to the extent to which these groups experience the activities of the Chinese in Ghana. Whereas the young, well-educated, well-resourced and 
dynamic large-scale Ghanaian importers view the Chinese as their fiercest competitors and thus demand their withdrawal, the relatively older people, who are also dissatisfied with the challenges associated with importing directly from China, though opposed to the Chinese, are willing to buy in bulk from the Chinese in Ghana. This option is economically sustainable only if the Chinese trading activities are restricted to the wholesale level, and is not a demand for them to be removed from the market. Similarly, Ghanaian traders who lack the capacity to import and are engaged in petty trading, final consumers, landlords, workers and business associates who find fortunes in the Chinese in the market space collaborate with them to enhance their wellbeing.

Finally, policy makers' failure to appreciate the nuances and the economic interest undergirding these responses as well as the fluidity that governs the clustering in the market space clearly explains the intractable and unsuccessful attempts at streamlining the activities of foreigners in the distribution sector. It is therefore, imperative on all stakeholders and discussants, to approach the phenomenon in a more multidimensional perspective if any success is to be envisaged.

\section{References}

Adjepong, A. 2009. The origins, implementation and effects of Ghana's 1969 aliens'compliance order (MPhil Thesis). Available on University of Cape Coast institutional

(http://ir.ucc.edu.gh/dspace/handle/123456789/1041)

repository

Alden, C. (2007) China in Africa. London: Zed Books.

Amoah A.G. L (2012). Africa in China: Affirming Agency in Africa-China Relationship at the People to people Level in James Shikwati (Ed.) ChinaAfrica Partnership; The quest for a Win-Win Relationship.

Armah. F.A., Luginaah, I.N., Taabazuing, J. Odoi J.O. (2013) Artisanal gold mining and surface water pollution in Ghana: have the foreign invaders come to stay? Environmental Justice 6(3): 94-102.

Ayittey, G.B.N. (1991) Why structural adjustment failed in Africa, TransAfrica Forum; Vol. 8 (2) 43-

Awumbila, A., Alhassan, O., Badasu, D.M., Antwi Bosiakoh, T. and Dankyi, E. K (2011). Socio-Cultural Dimensions of Migration in Ghana (Migration Technical Paper Series, Number 3). Accra: Woeli Publishing Services 
Bodomo, A. B. and Pajancic, C. (2016) Counting beans: Some empirical and methodological problems for calibrating the African presence in Greater China, in: Africans in China. Guangdong and Beyond (ed. Adams Bodomo), 2016. Diasporic Africa Press, New York.

Bodomo, A. B. (2012) Africans in China: A sociocultural study and its implications on Africa-China relations. New York: Cambria Press.

Bonacich, E. (1972) A Theory of Ethnic Antagonism: The Split Labor Market. American Sociological Review 37: 547-559

Bowles, L. R (2013) Transnational mobility, social capital, and cosmopolitan women traders in Ghana. African and Black Diaspora: An International Journal, 6(2) 208-217

Brautigam, D. (2009). The Dragon's Gift. The Real Story of China in Africa', Oxford: Oxford University Press.

Brautigam, D (2010). Chinese Development Aid in Africa: What, where, why, and how much? In China rising global challenges and opportunities (pp 203-222).

Branch, E. H. and C. Hanley, (2017) A Racial-Gender Lens on Precarious Nonstandard Employment Precarious Work. Research in the Sociology of Work, 31: 183-213

Brydon, L and Legge, K. (1996) Adjusting Society: The World Bank, the IMF and Ghana, I.B.Tauris

Castles, S. and Miller, M.J. (2009) The Age of Migration: International Population Movements in the Modern World. (fourth revised edition) Basingstoke and New York: Palgrave-Macmillan and Guilford Books

Cox, O. C. (1948) Caste, Class and Race. New York: Modern Reader

Darkwah, A. K. (2007). Making Hay while the Sun Shines: Ghanaian Female Traders and their Insertion into the Global Economy. In Gunewardena and A. Kingsolver (Eds). The Gender of Globalisation: Women Navigating Cultural and Economic Marginality, (61-83). Oxford: James Currey.

Darkwah A.K. (2002). Trading goes global: Ghanaian market women in an era of globalisation. Asian women 15, 31-49.

Danilovich J. (2006) The Private Sector as an Engine for Growth. Retrieved on February 21, 2018 from https://20012009.state.gov/p/af/rt/agoa/2006/68588.htm 
Dittgen, R. (2010) From Isolation to Integration? A study of Chinese Retailers in Dakar. SAIIA occasional paper No57. March 2010

Dobler, G. (2009) Chinese Shops and the Formation of a Chinese Expatriate Community in Namibia. The China Quarterly, 199, 707-727.

Downes, J. F. (2017) Mainland Chinese immigration in Hong Kong: Analysing anti- immigrant sentiment In Lem, W. and Cooper, L (Eds.) Citizenship, Identity and Social Identity in New Hong Kong: Routledge.

Ferguson, J. (2006) Global Shadows: Africa in the Neoliberal World Order. Duke University Press.

Freemantle, M. (2015) Trade patterns underline Africa's shifting role. Business Daily

Live. Retrieved on September 3, 2015 from http://www.bdlive.co.za/opinion/2015/05/25/trade-patterns-underlineafricas- shifting-role.

Fraser, A. and Lungu, J. (2007) For whom the windfalls? Winners and losers in the privatisation of Zambia's copper mines, Lusaka: Civil Society Trade Network of Zambia

Gadzala, A. W. (2010) From formal to informal-sector employment: Examining the Chinese presence in Zambia. Review of African Political Economy, 37(123) 41-59.

Gadzala, A.W. (2009) Survival of the fittest? Kenya's jua kali and Chinese businesses. Journal of Eastern African Studies. 3 (2), 202-220.

Garlick, P.C. (1971) African Traders and Economic Development in Ghana. Oxford: Clarendon Press.

Geddie, M.W., DeFranco, A. L and Geddie, M.F. (2002) From guanxi to customer relationship marketing: How the constructs of guanxi can strengthen CRM in the hospitality industry. Journal of Travel E Tourism Marketing 13(3), 19-33.

Giese, K. (2014) Beyond statistics: A qualitative look at the employment effects in the Chinese trade clusters of Ghana and Senegal. A DPRU Policy Brief: PB 14/37 Commissioned for the World Bank Group

Giese, K. and Thiel, A. (2012) The vulnerable other - distorted equity in Chinese-Ghanaian employment relations, Ethnic and Racial Studies, 1-20. 
Ghana Investment Promotion Centre Act 2013, Act 865. Retrieved on March 31st, 2015 from: $\quad$ http://www.gipcghana.com/press-andmedia/downloads/category/16-laws.html?download=43:gipc-act-2013-act-865

Ghana Investment Promotion Centre (GIPC). 2012, Annual Report, 2012. Ghana Investment Promotion Centre Act, 1994 ACT 478. Retrieved on March 31st , 2015 from: http://www.ghanatrade.gov.gh/file/gipc\%20laws/gipcact-478.pdf

Gu, J. (2009) China's Private Enterprises in Africa and the Implications for African Development. European Journal of Development Research 21, 570-587.

Haugen, H.O. (2011) Chinese exports to Africa: competition, complementarity and cooperation between Micro-Level Actors. Forum for Development Studies 38 (2), 157-176.

Harris, M. (1964) Patterns of Race in the Americas. New York: Walker.

Haugen, H. and Carling, J. (2005) On the edge of the Chinese diaspora: the surge of Baihuo business in an African city. Ethnic and Racial Studies, 28 (4), 639-62.

Hilson, GM, Hilson, AE and Adu-Darko, E. (2014) Chinese Participation in Ghana's Informal Gold Mining Economy: Drivers, Implications and Clarifications Journal of Rural Studies. 34:292-303

Ho, C.G.Y (2008) The 'doing' and 'undoing' of community: Chinese Networks in Ghana. China Aktuell 3, 45-76.

Hutchful, E. (2002) Ghana's adjustment experience. The paradox of reform, Geneva: UNRISD

Jacques J.M. (1980) The split labour market and ethnic antagonism: A case study in Higher Education. Sociology of Education 53(4):225-236.

Kaplinsky, R. and Morris, M. (2008) Do the Asian drivers undermine exportoriented industrialisation in SSA? World Development Special Issue on Asian Drivers

Konadu-Agyemang, K. (2002) IMF and World Bank Sponsored Structural Adjustment Programs in Africa: Ghana's Experience. Aldershot, U.K., and Burlington, Vt.: Ashgate,

Kotz, M. (2002) Globalisation and Neoliberalism. Rethinking Marxism 12 (2) 64-79 
Lampert, B. and Mohan, G. 2014. Sino-African Encounters in Ghana and Nigeria: From Conflict to Conviviality and Mutual Benefit, in: Journal of Current Chinese Affairs, 43, 1, 9-39.

Marfaing, L. and Thiel, A. (2011) The Chinese Commodity Imports in Ghana and Senegal: Demystifying Chinese Business Strength in Urban West Africa. GIGA WP180. Retrieved on April 11, 2012 from http://www.gigahamburg.de/dl/download.php?d=/content/publikatione $\underline{\text { n/pdf/wp180_marfaing-thiel.pdf }}$

McNamee, T. et al. (2012) Africa in their words: A study of Chinese traders in South Africa, Lesotho, Botswana, Zambia and Angola. (Discussion Paper 2012/03), The Brenthurst Foundation.

Mohan, G. and M. Tan-Mullins (2009). Chinese migrants in Africa as new agents of development? An analytical framework. European Journal of Development Research 21 (4): 588-605.

Nagle J. (2013). Unity in Diversity: non-sectarian social movement challenges to the politics of ethnic antagonism in violently divided cities. International Journal of Urban and Regional Research 37(1):78-92

Nkrumah, K. (1973). The Revolutionary Path. New York: International Publishers.

Obeng, M.K.M. (2015). Motivations, Networks and Strategies of Ghanaian Importers of Chinese Goods. Legon Journal of Sociology 5 (2), 59-82

Odutayo A. (2015). Conditional Development: Ghana Crippled by Structural Adjustment Programmes. Retrieved on February, 21, 2018 from http:// www.e-ir.info/2015/03/01/conditional-development-ghanacrippled-by-structural-adjustment-programmes/\#_ftn6

Kragelund, P. (2009) Knocking on a Wide-open Door: Chinese Investments in Africa. Review of African Political Economy, 36:122, 479-497

Rimmer, D. (1992) Staying Poor: Ghana's Political Economy, 1950-1990. Oxford: Pergamon Press.

Sautman, B. and Hairong, Y. (2007) Friends and interest: China's distinctive links with Africa. African Studies Review 50(2), 75-114.

Spring, A. (2009) Chinese development aid and agribusiness entrepreneurs in Africa.

Proceedings of the 10th Annual Conference of IAABD. Retrieved on March, 312015 from http://www.iaabd.org/2009_iaabd_proceedings/track2a.pdf 
Takyi-Boadu, C. (2005) Ghana's Retail Trade under Siege, in: The Chronicle, 9 November.

Taylor, I. (2007) 'China's relations with Nigeria: The round table. The Commonwealth Journal of International Affairs, 96(392), 631-645.

Tsikata, D., Fenny A.P., and Aryeetey E. (2008) China - Africa Relations: A Case Study of Ghana: A Draft Scoping Study Prepared for the African Economic Research Consortium http://www.aercafrica.org/documents/china_africa_relations/Ghana.pdf

Wang, J.Y. (2007) What Drives China's Growing Role in Africa? (IMF Working Paper 07/211). African Department, International Monetary Fund. Retrieved, February 27, 2014 from http://www.imf.org/external/pubs/ft/wp/2007/wp07211.pdf 